\title{
外傷性脳内血腫
}

一経時的 CT 検查所是に基つろいた分類についてー

$\begin{array}{llll}\text { 深町 } & \text { 彰・河野 } & \text { 和幸・若尾 } & \text { 哲夫 } \\ \text { 田崎 } & \text { 健・小泉 } & \text { 英仁・永関 } & \text { 慶重 }\end{array}$

\section{Traumatic Intracerebral Hematomas}

-A Classification According to the Dynamic Changes on Sequential CT's-

\author{
Akira Fukamachi, Kazuyuki Kohno, Tetsuo Wakao, Takeshi Tasaki, \\ Hidehito Koizumi and Yoshishige Nagaseki
}

Division of Neurosurgery, Yamanashi Prefectural Central Hospital

\begin{abstract}
Summary
After the introduction of CT (Hitachi CT-H) in February, 1977, we experienced 34 cases of traumatic intracerebral hematoma (ICH). In our previous report, we classified 11 cases of these into four groups based on the CT findings. In this paper, we modified certain parts of this classification, according to the dynamic changes on CT. The first group includes six cases whose ICH's were removed soon after the admission and one patient who expired shortly after the admission. The second group includes three cases whose initial CT's revealed small ICH's but repeat CT's disclosed large ones. The third group consists of eight cases whose ICH's were supposed to have developed out of cercbral contusion. The fourth group includes 16 cases whose ICH's shrinked or disappeared spontaneously.

From analytical studies of these groups, it was clarified that the enlargement or disappearance of the ICH on CT coincided well with the clinical deterioration or spontaneous improvement.

Recently, Brown, et al. and Diaz, et al. reported cases in which ICH's were demonstrated by repeat CT's and gave them the generic name of, "delayed traumatic ICH". We also experienced such cases, but we did not think that these patients had "delayed traumatic ICH's". From the analysis of our material, we considered that in these cases, evolution of ICH's could only be demonstrated by repeat CT's during the acute stage of the usual traumatic ICH's.
\end{abstract}

Key words : head injury, traumatic intracerebral hematoma, delayed traumatic intracerebral hematoma, cerebral contusion, computed tomography

\section{Iはじめに}

すでに我々は外傷性脳内血尰 1 例の computed tomography (CT) 所見について報告し，特に CT の経時的 観察の重要性を強調した ${ }^{8)}$. その後さらに23例の外傷性. 腷内血腫を程験 $\mathrm{L}, \mathrm{CT}$ 上の释時的変化に基づく外傷性 腷内血腫急性期動態の分類が臨床证侯の変化とよく一票
することが判明したのでここに報告する。

またこ扎ら3例中10例は，初回 CT では脳内血腫が 軽度かほとんど見られず，CTの経時的観察（1例は剖 搝)にて脙内血缠が明瞭になったものである。すなわ ちBrown $ら^{5 \prime}$, Diaz $ら^{6} \omega い 5$ "Delayed traumatic intracerebral hematomas"に相当するものと考えられるが，こ の点についても我々の考えを述べたい.

山梨県立中央病院脑神経外科

〔連絡先：

1979年 7 月 13 日 受稿 


\section{II対象ならびに方法}

CT（日立 CT-H scanner）を導入した1977年 2 月から 1979年 5 月までの 2 年 4 力月間に当科では，頭部外傷患 者598例に対し942回のCTを施行したＣＣにより診断 しえた頭蓋内病変は，硬膜外血腫42例，急性硬膜下血腫 18例，僈性硬膜下血腫 41 例，腷内血腫 35 例，硬膜下水腫 41 例，脳挫偒74例等であるが，今回注脳内血腫35例の5 ち入院の上経過観察しえた34例を検討の対象とした。

ここでいら脳内血腫と流，CT 上脳実質内に直径 1 $\mathrm{cm}$ 以上の大きさの出血走才高吸收域が見られた場合 をさした．記載の便宜上，脳内血腫の大きさを，高吸収 域の最大径 $1 \sim 3 \mathrm{~cm}$ 老小血腫, $3 \sim 5 \mathrm{~cm}$ 等大血 嗹， $5 \mathrm{~cm}$ 以上を大血腫とした ${ }^{82}$. 血腫の消長は plain $\mathrm{CT}$ での高吸收域の最大径, $\mathrm{x}$ 線吸収度值 ( $\mathrm{CT}$ 值)の変 化で判定した。 また脳内血缠に対する手術を施行した場 合は,その時点までの観察を検討の対象とした。

\section{II 結 果}

上記外傷性脳内血腫34例注短期日における経時的な $\mathrm{C}$

$\mathrm{T}$ の観察結果から，以下のように4 群に分類しえた.

第 1 群：急性血腫群(入院後速やかに手術を要したも のまたは早期に死亡したもの，Table 1)

本群沭前あるいは死亡前の CT での観察が 1 例を 除き 1 回のみであったもので，7例がこれに相当した。

これら 7 例はそのCT 所見からさらに以下の 2 群に細分 された.

\section{A) 腷内大血腫例}

本群に属したものは 5 例あり，4例が右前頭葉内大血 腫, 1 例が小譄虫部大血腫であった. 交通外傷 2 例, 軽 倒〜転落 3 例であり，initial unconsciousness 43 例に，

（半）清明期は 4 例に見られた，受傷上り入院までの時 間法，6時問以内 1 例， $6 \sim 12$ 時間 1 例， $12 \sim 24$ 時問 2 例，7 日後 1 例であった.

右前頭葉内血腫の 4 例梳, 入院時半昏睡 2 例, 昏迷 1 例，倾眠 1 例であり，昏迷以上の高度意識障害を呈して いた3 例（症例 1，2，3）はただちに手術（大開頭血腫 除去術，2 例に外隇圧術名併用.)を施行し，1 例に精神 症状を残した外悢好な結果寺得た，入院時候眼であっ た I例（症例 4）注当初経過を見たが，受傷より68時間 後には皆迷となり尿失禁む出現した. Repeat CT (Fig. 1)にて血腫自体の大きさは不変であったが，血腫周囲低 吸收域が明らかに增大していたため，手術を施行し好結 果索得た。小脳虫部大血腫の 1 例（症例 5 ）は落下し臂 部を强打して7 時間後に入院したが，深昏睡，呼吸停止，
睡孔散大の状態であった。気管内㨉管, 調節呼吸下に脳 室持続ドレナージを施行したが，死亡した．

B）急性硬膜下血腫に小中等大脳内血腫合併例

入院時 CT で急性硬膜下血腫が主体をなし，小〜中等 大脳内血腫が合併したものは2例めった(症例 6，7)。

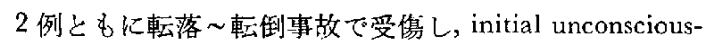
nessがなく清明期があったが，受傷上り 5 時間以内の入 院時には半昏睡であり瞳孔不同を呈していた。 CT 上も 2 例ともに, 硬膜下血腫の厚さほ約 $1 \mathrm{~cm}$ で片側层範囲 であり，脳内血腫は硬膜下血腫と同側で，脳室偏位が著 明であった。緊急手術（大開頭による硬膜下〜脳内血腫 除去，外減圧術）を施行したが，1例は救命しえ，1例 は死亡した。

第 2 群：腷内小血腫より大血腫に発達したむの( Table 2)

初回 CT では小血腫であったため経過をみたが,臨床 症候の増悪とともに CT 上譄内血腫の增大を見たもの で， 3 例が本群に相当した。 3 例已もに走行中のオート バイあるいはトラッタより転落したもので，症例 8，9 は兄弟例である. Initial unconsciousness 注 2 例に，清明 期注 1 例に見られた，受傷より $3.5 \sim 6$ 時間後に入院し たが，昏迷 2 例，傾眠 1 例であった．初回 CTでは 2 例 (症例 8，9) に右側頭葉内に最大径 $3.0 \mathrm{~cm}$ 以下の小 血腫が，1例（症例10）に右側頭葉内，左前頭葉内にそ れぞれ $3.0 １ .8 \mathrm{~cm}$ の血腫が見られた．受傷より 8 35.5 時間の経過で 3 例ともに意識レべルの増恶, 半身運 動麻瘦のH現または增強を見た. Repeat CT では全例に 扮いて媨内血腫の増大が明らかであり, 症例10では両血 腫ともに增大していた（Fig．2)，結局 3 例ともに脳内血 腫除去, 外減圧術を施行し（症例10は右側頭葉内血腫に 対してのみ施行)，現在全例復職しえている。

第 3 群：脳挫侮より脳内血腫形成をみたもの（Table 3)

本群の中には，初回 CT で salt and pepper appearance から成る出血性媨挫傷所見を呈し repeat CT または剖 検で腷内血腫形成をみた 4 例（症例11～14）, 初回 CTで 異常をみなかった部位に脑内血腫形成をみた 3 例（症例 15１7），抢よび集簇した血腫の状態から脱挫傷由来と考

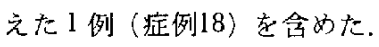

症例11 I4の4 症例初回 CT で出血性媨挫傷上診 断し，保存的治療を施行していくうちに脳内血腫形成索 確認したものである。交通外傷 2 例，転落 2 例で， ini一 tial unconsciousness 3 例飞，(半) 清明期は全例に見 られた。 4 例ともに受稘より $2 \sim 6.5$ 時間の短時間に入 院しているが，入院時意識レベルは昏迷 2 例，傾眠 1 
Tables 1-4: Classification of traumatic intracerebral hematomas according to the sequential CT changes.

Table 1 The first group : Six cases whose intracerebral hematomas were removed soon after the admission and one case who cxpired shortly after the admission.

Group 1-A : Large intracerebral hematomas; five cases

\begin{tabular}{|c|c|c|c|c|c|c|c|c|c|}
\hline $\begin{array}{l}\text { Case } \\
\text { No. }\end{array}$ & $\begin{array}{l}\text { Age } \\
\text { (yrs) }\end{array}$ & Sex & $\begin{array}{l}\text { Location of } \\
\text { bruise }\end{array}$ & $\begin{array}{l}\text { Clinical findings on } \\
\text { admission }\end{array}$ & Later clinical findings & Initial CT findings & Repeat CT findings & $\begin{array}{l}\text { Opera- } \\
\text { tion }\end{array}$ & Result \\
\hline 1 & 8 & $\mathrm{~m}$ & $\begin{array}{l}\text { R-frontal } \\
\text { region }\end{array}$ & $\begin{array}{l}(5 \mathrm{hrs}) \\
\text { Semicoma } \\
\text { L-hemiplegia } \\
\text { Black eyes }\end{array}$ & & $\begin{array}{l}(5 \mathrm{hrs}) \\
\text { R-frontal ICH } \\
\qquad(5.5 \mathrm{~cm})\end{array}$ & & + & Good \\
\hline 2 & 44 & $\mathrm{~m}$ & $\begin{array}{l}\text { R-frontal } \\
\text { region }\end{array}$ & $\begin{array}{l}\text { (14 hrs) } \\
\text { Semicoma } \\
\text { Anisocoria }(\mathrm{L}<\mathrm{R}) \\
\text { L-Hemiplegia } \\
\text { Decerebrate posture } \\
\text { Respiratory distress }\end{array}$ & & $\begin{array}{l}\text { (14 hrs) } \\
\text { R-frontal ICH } \\
\qquad(6.0 \mathrm{~cm}) \\
\text { Ventricular hemorrhage }\end{array}$ & & + & Fair \\
\hline 3 & 52 & $\mathrm{~m}$ & $\begin{array}{l}\text { Occiput } \\
\text { R-eye }\end{array}$ & $\begin{array}{l}\text { (7 days) } \\
\text { Stupor } \\
\text { Choked disc } \\
\text { Headache } \\
\text { Vomiting }\end{array}$ & & $\begin{array}{l}(7 \text { days }) \\
\text { R-frontal } 1 \mathrm{CH} \\
\qquad 5.0 \mathrm{~cm})\end{array}$ & & + & Good \\
\hline 4 & 65 & $\mathrm{~m}$ & Vertex & $\begin{array}{l}(20.5 \mathrm{hrs}) \\
\text { Somnolence } \\
\text { Headache }\end{array}$ & $\begin{array}{l}\text { (68 hrs) } \\
\text { Stupor } \\
\text { Urinary incontinence } \\
\text { Headache }\end{array}$ & $\begin{array}{l}(20.5 \mathrm{hrs}) \\
\text { R-frontal } \mathrm{ICH} \\
\qquad(6.2 \mathrm{~cm})\end{array}$ & $\begin{array}{l}\text { (68 hrs) } \\
\text { ICH: stationary } \\
\text { Perifocal LD: increased }\end{array}$ & + & Good \\
\hline 5 & 3 & $\mathrm{f}$ & Buttock & $\begin{array}{l}\text { ( } 7 \text { hrs) } \\
\text { Deep coma } \\
\text { Respiratory arrest } \\
\text { Dilated pupils } \\
\text { No light reflex }\end{array}$ & & $\begin{array}{l}\text { (7 hrs) } \\
\text { Vermis ICH }(5.0 \mathrm{~cm}) \\
\text { Hydrocephalus } \\
\text { Ventricular hemorrhage }\end{array}$ & & CVD & Died \\
\hline \multicolumn{10}{|c|}{ Group 1-B: Small or medium-sized intracerebral hematomas associated with acute subdural hematomas; two cases } \\
\hline 6 & 50 & $\mathrm{~m}$ & Vertex & $\begin{array}{l}\text { (4 hrs) } \\
\text { Semicoma } \\
\text { Anisocoria }(\mathbf{L}<\mathbf{R}) \\
\text { Decerebrate posture }\end{array}$ & & $\begin{array}{l}(4 \mathrm{hrs}) \\
\text { R-acute SDH } \\
\text { R-frontal ICH } \\
\qquad(4.5 \mathrm{~cm})\end{array}$ & & + & Dicd \\
\hline 7 & 52 & $\mathrm{~m}$ & $\begin{array}{l}\text { L-temporal } \\
\text { region }\end{array}$ & $\begin{array}{l}\text { (4.5 hrs) } \\
\text { Semicoma } \\
\text { Anisocoria }(\mathrm{L}>\mathrm{R}) \\
\text { R-hemiplegia }\end{array}$ & & $\begin{array}{l}(4.5 \mathrm{hrs}) \\
\text { L-acute SDH } \\
\text { L-temporal ICH } \\
\qquad(2.2 \mathrm{~cm})\end{array}$ & & + & Good \\
\hline
\end{tabular}




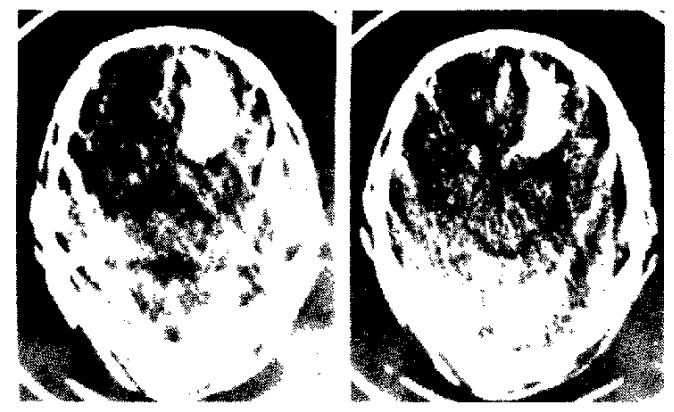

CT-1 (20. 5 hrs)

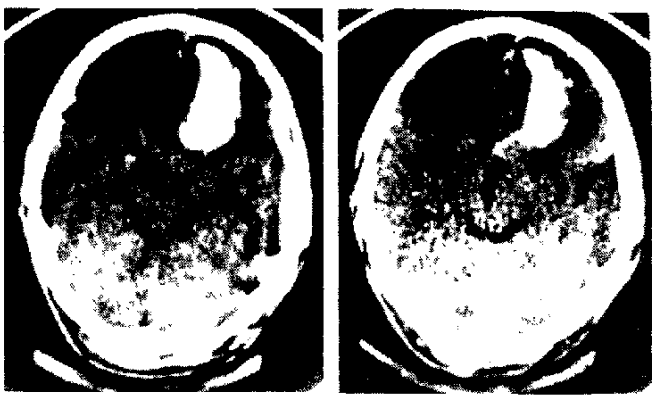

CT-2(68 hrs)

Fig. 1 Sequential CT's of Case 4. Note the frontal perifocal low density on the second CT.

例，清明 1 例であった。このうち 3 例（症例11 13）忚 受傷後 6.5 43.5 時間には明らかに意識レベルの低下， 眖孔不同の出現等をみ, repeat CT上全例飞脱內血腫の

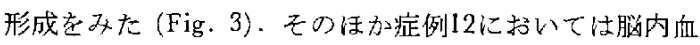
腫周囲低吸収域の增大が，症例13においては急性硬膜下 血缠の堌大が著明であった，2例(症例 11，12) に腷内血 腫除去,外減圧術を施行し好結果を得たが，1例(症例13) は急激な経過をとり死亡した，残りの1例(症例14) 法， 入院時 CT (Fig. 4A）では右急性硬膜外血腫が主体で あり同血腫に対する血腫除去と外減压術を施行したが， 意織障害が増恶し術後 7 日目に死亡, 剖検 (Fig. 4B)に て右前頭葉内大血腫の存在が確諗されたるのである.

症例15 17D3 症例は, 初回 CT で特に異常所見を認 めなかった部位に脳内血腫形成をみたものである，3 例 上も交通事故による受傷で, initial unconsciousness は 2 例に，清明期も 2 例にみられた，全例受稘後 $1 \sim 5$ 時間 で入院したが，す心゙て筸迷状態であった，このらち2例 （症例16，17）は受傷後40～56時間にそれぞれ半毕睡， 重度皆迷となり睑孔不同の出現をみた。初回CTではそ れぞれ小さな硬膜外䘏腫，左シルビウス裂内ク王膜下出 血の所見程度であったが， repeat CT では症例16に扰い ては右前頭葉, 右倒頭葉, 左前頭背内に最大径 $2.8 \mathrm{~cm}$ の多発性脑内血腫所見壱み，症例17（Fig. 5) において は右側頭葉内大血腫形成抢よび左倒頭葉出血性挫傷の所

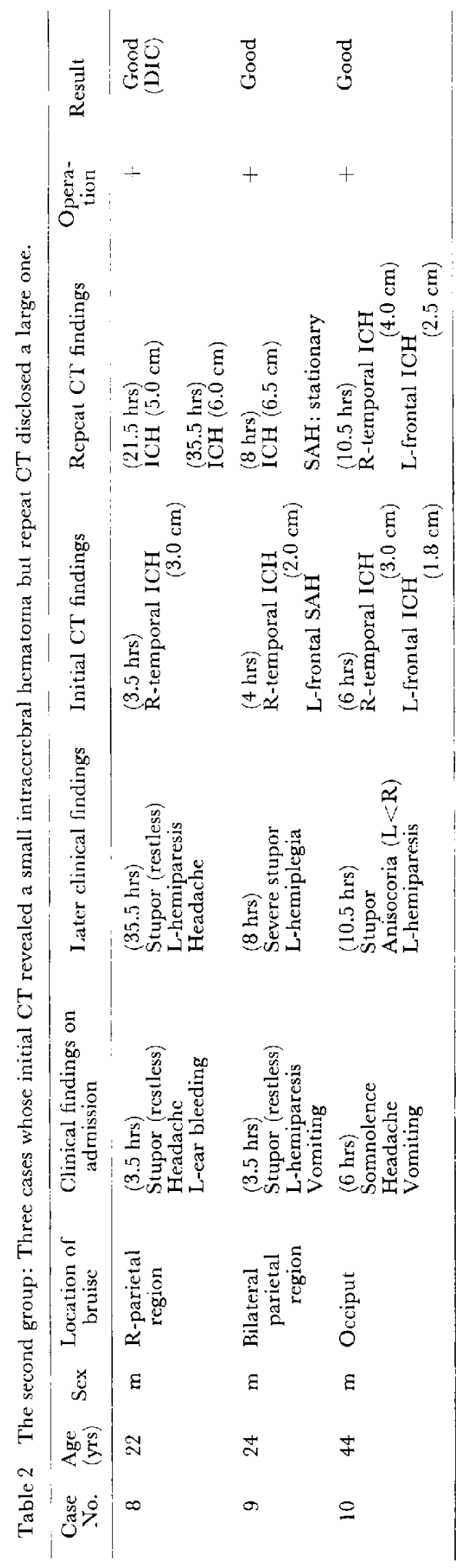



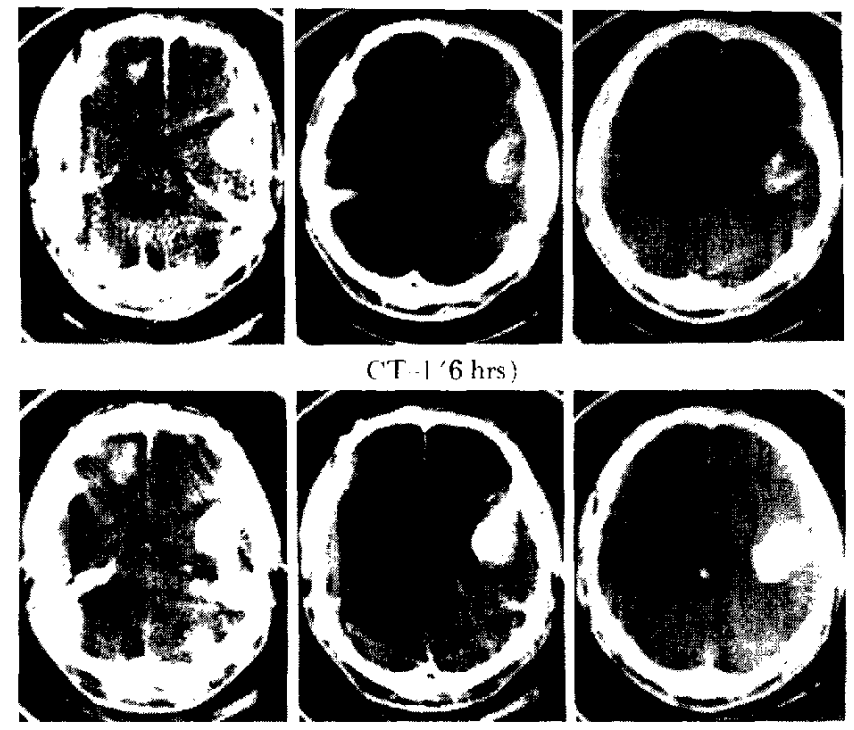

CT-2(10.5 hrs)

Fig. 2 Sequential CT's of Case 10. Note an enlargement of the left frontal and right temporal ICH's.
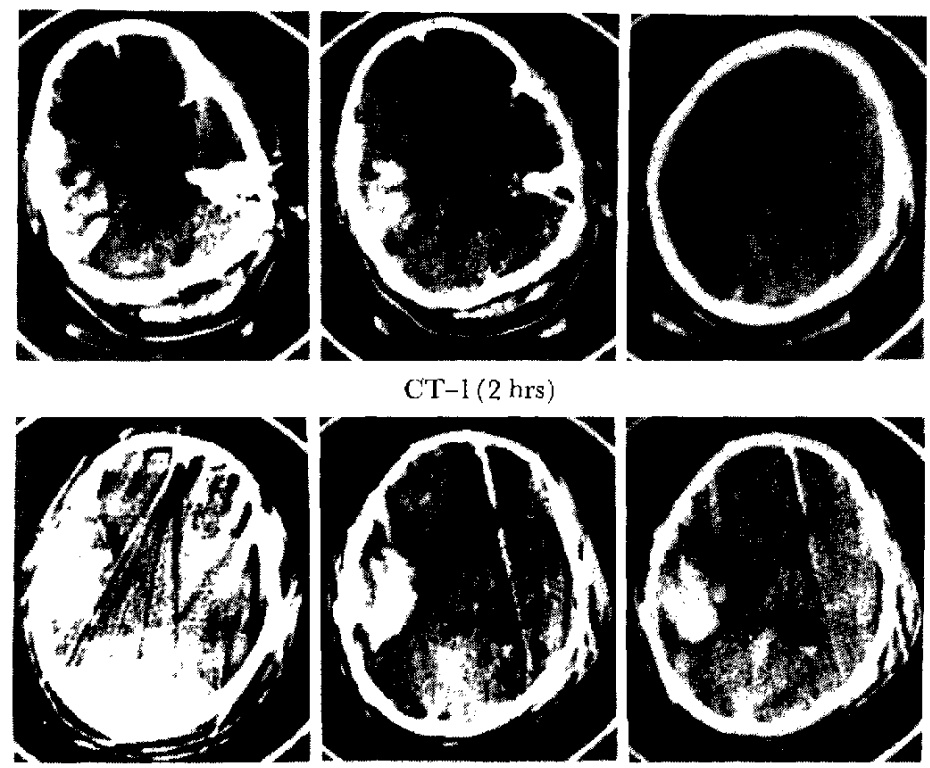

CT-2(43.5 hrs)

Fig. 3 Sequential CT's of Case 11. Initial CT shows the hemorrhagic contusion in the left temporal lobe, but the sccond CT discloses the formation of $\mathrm{ICH}$.

見を得た。症例16は多発性腷内小血腫でも㐫りステロイ ド大量投与にて経過をみたところ好結果奔得たが, 症例 17は雨側外減圧, 右側頭葉内血腫除去術施行後播種性血 管内凝固症候群(DIC)の合併にて死亡した. 残りのI例 （症例15）沬初回 CT では左急性硬膜下拈上び硬膜外血 腫上診断し，緊急手術により血婳除去と外娍圧術を施行
した.しかし術後意識レベルの回復が不良のため10日後 CT再検をしたところ，左前頭葉内血腫形成を認めた。 㨫内血腫に対する手術は施行せず経過をみたが，徐々に 意識レベルの回復が見られた。

症例18（Fig. 6) は左側頭葉内, 右前頭葉内に血腫形 成をみたが，その血盾の様相からともに腷挫賃由来と考 
Table 3 The third group: Eight cases whose intracerebral hematomas were supposed to have developed out of ccrebral contusions.

\begin{tabular}{|c|c|c|c|c|c|c|c|c|c|}
\hline $\begin{array}{l}\text { Case } \\
\text { No. }\end{array}$ & $\begin{array}{l}\text { Age } \\
\text { (yrs) }\end{array}$ & Sex & $\begin{array}{l}\text { Location of } \\
\text { bruise }\end{array}$ & $\begin{array}{l}\text { Clinical findings on } \\
\text { admission }\end{array}$ & Later clinical findings & Initial CT findings & Rcpeat CT findings & $\begin{array}{c}\text { Opera- } \\
\text { tion }\end{array}$ & Result \\
\hline 11 & 48 & $\mathbf{m}$ & $\begin{array}{l}\text { R-parietal } \\
\text { region }\end{array}$ & $\begin{array}{l}(2 \mathrm{hrs}) \\
\text { Stupor (rcstlcss) } \\
\text { Anisocoria }(L>R) \\
\text { R-ear bleeding }\end{array}$ & $\begin{array}{l}\text { ( } 43.5 \text { hrs) } \\
\text { Severc stupor } \\
\text { Anisocoria } \\
\quad \text { (L: mydriasis) } \\
\text { R-hemiplegia } \\
\text { Apnea at times }\end{array}$ & $\begin{array}{l}(2.5 \mathrm{hrs}) \\
\text { L-temporal contusion }\end{array}$ & $\begin{array}{l}(43.5 \mathrm{hrs}) \\
\mathrm{L} \text {-temporal ICH } \\
\qquad(6.5 \mathrm{~cm})\end{array}$ & \multicolumn{2}{|c|}{$\begin{array}{l}\text { (Reaccumulation } \\
\text { of } \mathrm{ICH})\end{array}$} \\
\hline 12 & 58 & $\mathrm{f}$ & Occiput & $\begin{array}{l}\text { (6.5 hrs) } \\
\text { Somnolence } \\
\text { Nuchal stiffness } \\
\text { Vomiting }\end{array}$ & $\begin{array}{l}(22.5 \mathrm{hrs}) \\
\text { Semicoma } \\
\text { Anisocoria }(\mathrm{L}>\mathrm{R})\end{array}$ & $\begin{array}{l}\text { (6.5 hrs) } \\
\text { L-frontal contusion } \\
\text { L-acute SDH (thin) }\end{array}$ & $\begin{array}{l}(22.5 \mathrm{hrs}) \\
\mathrm{L}-\text { frontal } \mathrm{ICH} \\
\qquad(2.0 \mathrm{~cm}) \\
\text { L-frontal LD-SDH: } \\
\text { increased }\end{array}$ & + & Good \\
\hline 13 & 78 & $\mathrm{~m}$ & $\begin{array}{l}\text { Bilateral } \\
\text { parieto- } \\
\text { occipital } \\
\text { region }\end{array}$ & $\begin{array}{l}\text { (3 hrs) } \\
\text { Alcrt } \\
\text { R-hemiparcsis } \\
\text { R-ear bleeding }\end{array}$ & $\begin{array}{l}(6.5 \mathrm{hrs}) \\
\text { Semicoma } \\
\text { Anisocoria }(L>R)\end{array}$ & $\begin{array}{l}(3 \mathrm{hrs}) \\
\text { L-temporal contusion } \\
\text { L-acute SDH (thin) }\end{array}$ & $\begin{array}{l}(6.5 \mathrm{hrs}) \\
\text { L--temporal ICH } \\
\quad(7.0 \mathrm{~cm}) \\
\text { SDH: increased }\end{array}$ & - & Died \\
\hline 14 & 52 & $\mathrm{~m}$ & $\begin{array}{l}\text { R-frontal } \\
\text { region }\end{array}$ & $\begin{array}{l}\text { (2 hrs) } \\
\text { Stupor } \\
\text { Anisocoria }(L<R)\end{array}$ & $\begin{array}{l}\text { (After EDH removal) } \\
\text { Semicoma-Coma } \\
\text { (7 days) Died }\end{array}$ & $\begin{array}{l}(2 \mathrm{hrs}) \\
\mathrm{R} \text {-acute EDH } \\
\text { R-frontal contusion }\end{array}$ & $\begin{array}{l}\text { Autopsy) } \\
\text { R-frontal ICH } \\
\quad \text { (large) }\end{array}$ & - & Died \\
\hline 15 & 46 & $\mathrm{~m}$ & $\begin{array}{l}\mathrm{R} \text {-occipital } \\
\text { region }\end{array}$ & $\begin{array}{l}(1 \mathrm{hr}) \\
\text { Stupor } \\
\text { Anisocoria }(\mathbf{L}>\mathrm{R}) \\
\text { R-hemiparesis }\end{array}$ & $\begin{array}{l}\text { (After SDH-EDH } \\
\text { removal) } \\
\text { Improvement was } \\
\text { not good. }\end{array}$ & $\begin{array}{l}(1 \mathrm{hr}) \\
\text { L-acute SDH-EDH }\end{array}$ & $\begin{array}{l}\text { (10 days) } \\
\text { L-frontal ICH } \\
\qquad 2.5 \mathrm{~cm})\end{array}$ & - & Good \\
\hline 16 & 39 & $\mathbf{m}$ & $\begin{array}{l}\text { L-parietal } \\
\text { region }\end{array}$ & $\begin{array}{l}\text { (5 hrs) } \\
\text { Stupor } \\
\text { Vomiting } \\
\text { Shock }\end{array}$ & $\begin{array}{l}\text { (40 hrs) } \\
\text { Semicoma } \\
\text { Anisocoria }(L<R) \\
\text { Bradycardia }\end{array}$ & $\begin{array}{l}(5 \mathrm{hrs}) \\
\text { L-acute EDH (small) }\end{array}$ & $\begin{array}{l}\text { (40 hrs) } \\
\text { R-frontal, temporal, } \\
\text { L-temporal ICH's } \\
\quad \text { (all } 2.8 \mathrm{~cm} \text { ) } \\
\text { EDH: stationary }\end{array}$ & - & Good \\
\hline 17 & 63 & $f$ & $\begin{array}{l}\text { Bilateral } \\
\text { temporal } \\
\text { region }\end{array}$ & $\begin{array}{l}\text { (1 hr) } \\
\text { Stupor (restless) } \\
\text { Vomiting } \\
\text { R-ear bleeding }\end{array}$ & $\begin{array}{l}\text { (56 hrs) } \\
\text { Severe stupor } \\
\text { Anisocoria }(L>R)\end{array}$ & $\begin{array}{l}(1 \mathrm{hr}) \\
\mathrm{L}-\mathrm{SAH}\end{array}$ & $\begin{array}{l}(56 \mathrm{hrs}) \\
\text { R-temporal ICH } \\
\quad(5.0 \mathrm{~cm}) \\
\text { L-temporal contusion }\end{array}$ & + & $\begin{array}{l}\text { Died } \\
\text { (DIC) }\end{array}$ \\
\hline 18 & 60 & $\mathrm{~m}$ & $\begin{array}{l}\text { L-temporal } \\
\text { region }\end{array}$ & $\begin{array}{l}\text { (16 hrs) } \\
\text { Deteriorated } \\
\text { in other hospital }\end{array}$ & $\begin{array}{l}\text { (19 hrs) } \\
\text { Deep coma } \\
\text { Dilated pupils } \\
\text { No light reflex } \\
\text { Respiratory arrest }\end{array}$ & $\begin{array}{l}(16 \mathrm{hrs}) \\
\text { L-temporal ICH } \\
\qquad(6.0 \mathrm{~cm}) \\
\text { R-frontal ICH } \\
\qquad(3.0 \mathrm{~cm})\end{array}$ & $\begin{array}{l}\text { (19 hrs) } \\
\text { Both ICH's: stationary } \\
\text { Brain stem hemorrhage }\end{array}$ & - & Died \\
\hline
\end{tabular}




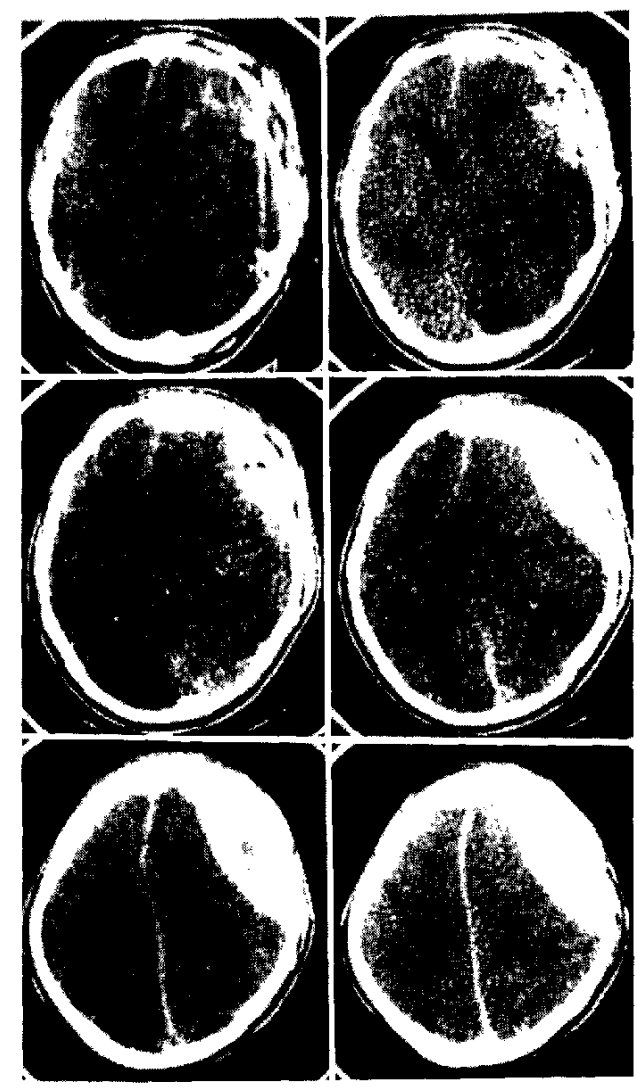

A
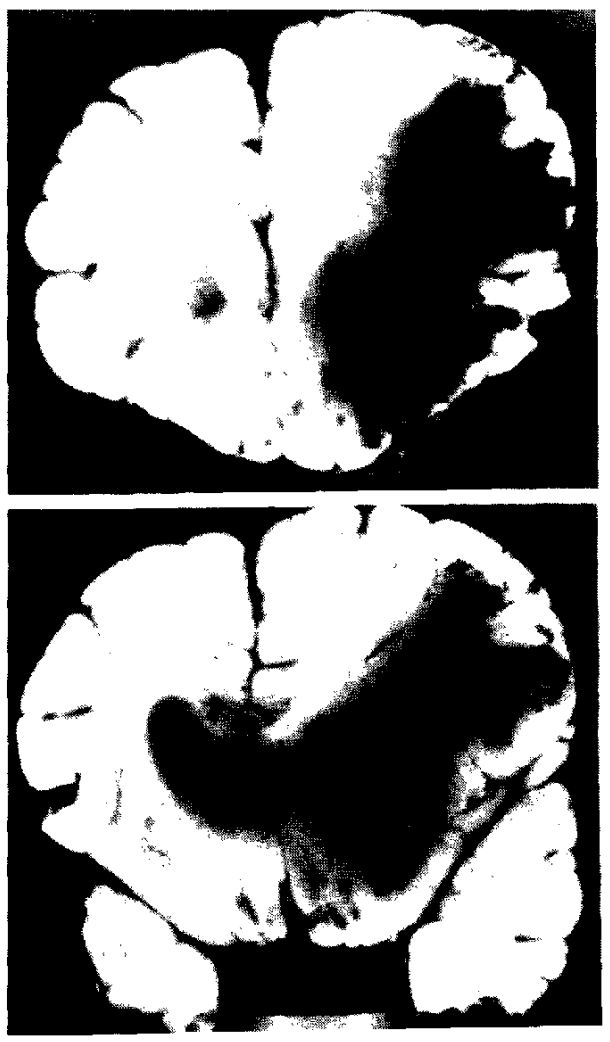

B

Fig. 4 A: CT of Case 14. Note the large epidural hematoma and the hemorrhagic contusion in the right frontal lobe.

B: Autopsied brain of Case 14. Note the large intracerebral hematoma in the right frontal lobe.

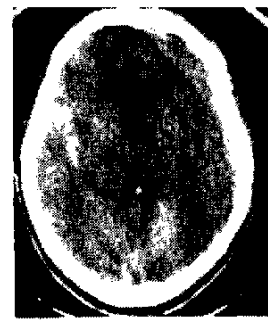

CT-l(1hr)

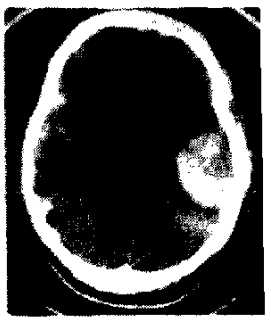

CT $-2(56 \mathrm{hrs})$

Fig. 5 Sequential CT's of Case 17. Note the normal initial CT and the subsequent formation of $\mathbf{I C H}$ in the right temporal lobe.

え本群の中に加えた，左側頭葉内血腫は受賃後 16 時間の

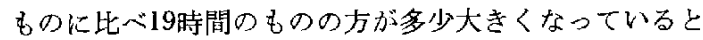
思われたが，本例に特幑的なことはこの3 時間のらちに 二次的と考えられる脳幹出血が完成し，これをCTで証 明しえたことである、臨床的には initial unconsciousness はみられたが数時間は傾眠程度で步行も仃能であった。

7 時間後より意識レベルの低下があり，19時間後来院時 にはすでに深昏睡, 自発呼吸停止の状態であった。

第 4 群：脑内血腫が樎小ないし 消失したもの(Table 4)

初回 CT で膊内血腫を確認したが，臨床症候の改善 とともに CT 上血腫を示寸高吸収城が縮小ないし消失 したもの（大きさが不変でも CT 值が堿少した例も含 めたは16例であった．初回 CT で大血腫のすの4例 (症例19 22), 中等大血腫の\&の4例（症例23 26), 小 血婳のもの8例（症例27〜34）であった.

交通外傷 3 例，転落〜転倒12例，石が当ったもの1例 であり，initial unconsciousness は10例にあり，(半) 清 明期は14例に見られた，受傷より入院东での期間は1時 間加ら22日にわたって扣り，入院時意識レベル俚半昏睡 2 例，昏迷 4 例，傾眠 6 例，清明 4 例でるった，16例中 3 例に招いては腷内血腫以外の病態に対し外科的処置を 行ったが，腷内血腫自体に対しては全例経過をみた。 
Table 4 The fourth group: 16 cases whose intracerebral hematomas shrinked or disappeared spontancously.

\begin{tabular}{|c|c|c|c|c|c|c|c|c|c|}
\hline $\begin{array}{l}\text { Case } \\
\text { No. }\end{array}$ & $\begin{array}{l}\text { Age } \\
(y r s)\end{array}$ & Sex & $\begin{array}{l}\text { Location of } \\
\text { bruise }\end{array}$ & $\begin{array}{l}\text { Clinical findings on } \\
\text { admission }\end{array}$ & Later clinical findings & Initial CT findings & Repeat $C T$ findings & $\begin{array}{l}\text { Opera- } \\
\text { tion }\end{array}$ & Result \\
\hline 19 & 9 & $\mathrm{~m}$ & Face & $\begin{array}{l}\text { (6 days) } \\
\text { Severe headache } \\
\text { Vomiting }\end{array}$ & $\begin{array}{l}\text { (27 days) } \\
\text { Symptoms: } \\
\quad \text { disappeared }\end{array}$ & $\begin{array}{l}\text { (6 days) } \\
\text { R-temporal } \mathrm{ICH}(5.5 \mathrm{~cm}) \\
\text { Ventricular } \\
\text { hemorrhage } \\
\text { Dandy-Walker syndrome }\end{array}$ & $\begin{array}{l}\text { (27 days) } \\
\text { ICH: disappeared } \\
\text { VH: disappeared } \\
\text { Dandy-Walker: } \\
\text { stationary }\end{array}$ & CVD & Good \\
\hline 20 & 53 & $\mathrm{~m}$ & Forehcad & $\begin{array}{l}\text { (2l.5 hrs) } \\
\text { Stupor (restless) } \\
\text { R-herniparesis }\end{array}$ & $\begin{array}{l}\text { (24 days) } \\
\text { Almost alert } \\
\text { Amnestic aphasia } \\
\text { Headache }\end{array}$ & $\begin{array}{l}\text { (21.5 hrs) } \\
\text { L-temporal ICH } \\
\qquad 5.5 \mathrm{~cm}) \\
\text { Ventricular } \\
\text { hemorrhage } \\
\text { R-acute EDH (small) }\end{array}$ & $\begin{array}{l}\text { (24 days) } \\
\text { ICH }(1.0 \mathrm{~cm}) \\
\text { VH-LDH: disappeared } \\
\text { Ventricular } \\
\quad \text { enlargement (mild) }\end{array}$ & - & Good \\
\hline 21 & 6 & $\mathrm{~m}$ & Forehead & $\begin{array}{l}\text { (17 hrs) } \\
\text { Headache } \\
\text { Vomiting } \\
\text { L-hcmiparesis } \\
\text { Convulsion }\end{array}$ & $\begin{array}{l}\text { (13 days) } \\
\text { Symptoms: } \\
\text { disappeared }\end{array}$ & $\begin{array}{l}(17 \mathrm{hrs}) \\
\text { R-parietal ICH } \\
\qquad 5.5 \mathrm{~cm})\end{array}$ & $\begin{array}{l}\text { ( } 13 \text { days }) \\
\text { ICH }(4.0 \mathrm{~cm}) \\
\text { ( } 50 \text { days) } \\
\text { ICH : disappeared }\end{array}$ & - & Good \\
\hline 22 & 74 & $\mathrm{~m}$ & Occiput & $\begin{array}{l}\text { ( } 3 \text { days) } \\
\text { Somnolence } \\
\text { Headache }\end{array}$ & $\begin{array}{l}\text { (11 days) } \\
\text { Stupor } \\
\text { Headache } \\
\text { ( } 30 \text { days) } \\
\text { Alert }\end{array}$ & $\begin{array}{l}\text { (3 days) } \\
\text { L-frontal ICH } \\
\text { R-frontal ICH }(5.8 \mathrm{~cm}) \\
\qquad(5.0 \mathrm{~cm})\end{array}$ & $\begin{array}{l}\text { (11 days) } \\
\text { Both ICH's: stationary } \\
\text { (30 days) } \\
\text { ICH's: disappeared }\end{array}$ & - & Good \\
\hline 23 & 75 & $\mathrm{~m}$ & Occiput & $\begin{array}{l}\text { (22 days) } \\
\text { Somnolence } \\
\text { Urinary incontinence } \\
\text { L-hemiparesis }\end{array}$ & $\begin{array}{l}\text { (After chronic SDH } \\
\text { removal) } \\
\text { Symptoms: improved } \\
\text { soon }\end{array}$ & $\begin{array}{l}(22 \text { days }) \\
\text { R-chronic SDH } \\
\text { R-frontal ICH } \\
\qquad(4.0 \mathrm{~cm})\end{array}$ & $\begin{array}{l}\text { (39 days) } \\
\text { SDH: shrinked } \\
\mathrm{ICH}(1.5 \mathrm{~cm})\end{array}$ & - & Good \\
\hline 24 & 33 & $\mathrm{~m}$ & $\begin{array}{l}\text { L-temporal } \\
\text { region }\end{array}$ & $\begin{array}{l}\text { (4 days) } \\
\text { Somnolence } \\
\text { Headache }\end{array}$ & $\begin{array}{l}\text { (10 days) } \\
\text { Symptoms: } \\
\text { disappeared }\end{array}$ & $\begin{array}{l}\text { (4 days) } \\
\text { R-temporal ICH } \\
\qquad(3.8 \mathrm{~cm})\end{array}$ & $\begin{array}{l}(11 \text { days }) \\
\mathrm{ICH}(2.2 \mathrm{~cm})\end{array}$ & - & Good \\
\hline 25 & 69 & $\mathrm{~m}$ & $\begin{array}{l}\text { R-temporal } \\
\text { region }\end{array}$ & $\begin{array}{l}(5 \mathrm{hrs}) \\
\text { Headache } \\
\text { Vomiting } \\
\text { Anisocoria }(\mathrm{L}<\mathrm{R})\end{array}$ & $\begin{array}{l}\text { (6 days) } \\
\text { Hcadache } \\
\text { (14 days) } \\
\text { Symptoms: } \\
\text { disappeared }\end{array}$ & $\begin{array}{l}(5 \mathrm{hrs}) \\
\text { R-tcmporal ICH } \\
\qquad 4.0 \mathrm{~cm})\end{array}$ & $\begin{array}{l}\text { (6 days) } \\
\text { ICH: stationary } \\
\text { L-SD hygroma (thin) } \\
\text { (14 days) } \\
\text { ICH: disappeared } \\
\text { Hygroma: stationary }\end{array}$ & - & Good \\
\hline 26 & 69 & $\mathrm{~m}$ & Occiput & $\begin{array}{l}\text { (47 hrs) } \\
\text { Stupor (restless) } \\
\text { Vomiting } \\
\text { Neck stiffness }\end{array}$ & $\begin{array}{l}\text { (9 days) } \\
\text { Somnolence } \\
\text { Neck stiffness } \\
\text { Headache }\end{array}$ & $\begin{array}{l}(47 \mathrm{hrs}) \\
\text { L-frontal ICH } \\
\text { R-SD hygroma }\end{array}$ & $\begin{array}{l}\text { (9 days) } \\
\text { ICH } \\
\text { size: stationary } \\
\text { density: decreased } \\
\text { Hygroma: increased }\end{array}$ & - & $\begin{array}{l}\text { Died } \\
\text { (due to } \\
\text { gastro- } \\
\text { intestinal } \\
\text { bleeding) }\end{array}$ \\
\hline 27 & 13 & $\mathrm{~m}$ & $\begin{array}{l}R \text {-frontal } \\
\text { region }\end{array}$ & $\begin{array}{l}\text { (3 hrs) } \\
\text { Somnolence } \\
\text { Headache } \\
\text { Vomiting }\end{array}$ & $\begin{array}{c}\text { Symptoms: improved } \\
\text { soon }\end{array}$ & $\begin{array}{l}(3 \mathrm{hrs}) \\
\text { R-frontal ICH } \\
\qquad 2.6 \mathrm{~cm})\end{array}$ & $\begin{array}{l}\text { (4 days) } \\
\text { ICH: stationary } \\
\text { (18 days) } \\
\text { ICH: disappeared }\end{array}$ & - & Good \\
\hline
\end{tabular}




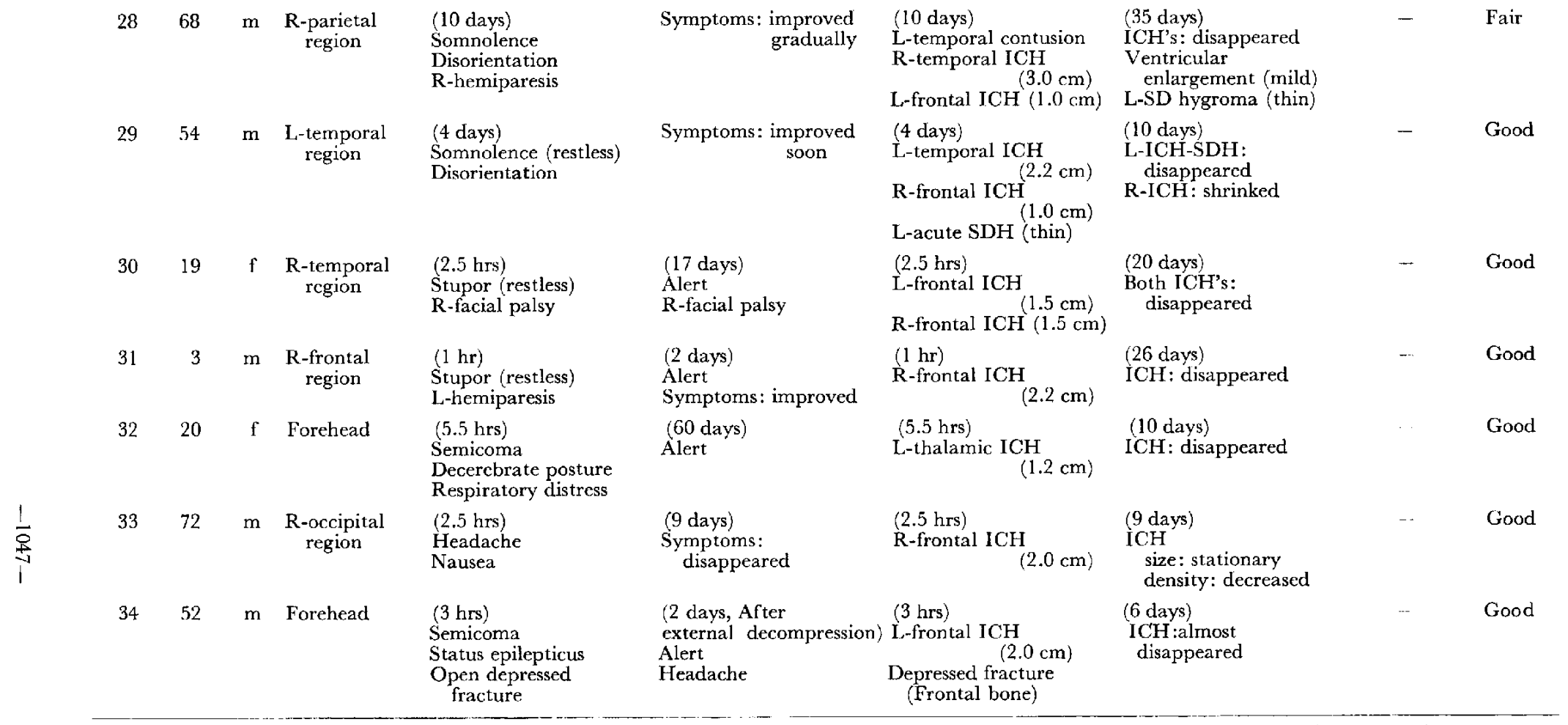

Hours or days in parentheses denote the time intervals from head injury. Centimcter in parentheses means the maximum diameter of intracerebral hematoma on $\mathrm{CT} . \mathrm{m}=$ male, $\mathrm{f}=$ female, $\mathrm{L}=$ left, $\mathrm{R}=$ right, $\mathrm{CT}=$ computed tomograpry, $\mathrm{ICH}=$ intracerebral hematoma, $\mathrm{SDH}=$ subdural hematoma, $\mathrm{EDH}=$ epidural hematoma, $\mathrm{SAH}=$ subarachnoid hemorrhage, $\mathrm{SD}=$ subdural, $\mathrm{VH}=$ ventricular homorrhage, $\mathrm{LD}=$ low density, $\mathrm{CVD}=$ continuous ventricular drainage and $\mathrm{DIC}=$ disseminated intravascular coagulation 

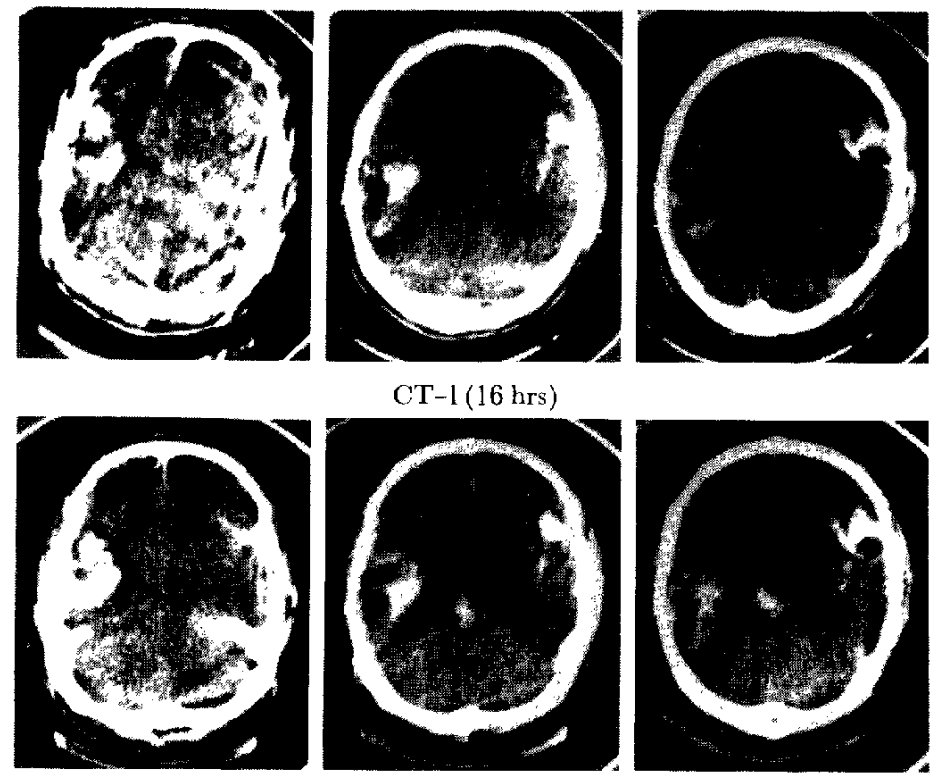

CT-2(19 hrs)

Fig. 6 Sequential CT's of Case 18. The secondary hemorrhage of brain stem was noted on the second CT.

の結果初回 CT で脳内大血腫と診断した 4 例をも含め て全例臨床症候の改善をみ，それに伴いCT 上の血䡛 の大きさも減少していた（Fig. 7).しかし血腫の大きさ と臨床症候の改善の早さは必ずしも相関せず，小血腫と いえどる改善が遅い例(症例28，30，32，33)があった。 半皆睡であった 2 例（症例32，34）はいずれす小血腫で あり，脳内血腫除去の対象とならなかったるのである。 なお 1 例（症例26）は症状の軽快をみていたが，外倁11 日後に大量の胃腸管出血を合併し死亡した。

脳内血腫以外の病態に対し外科的処置を施行したもの は3 例（症例19，23，34）であった，症例19は右侧頭葉 内大血腫の外に Dandy-Walker 症候群を合伊していた例 で，持続脳室ドレナージに上り症状の改善をみた，症例 23 は右前頭葉内血腫とともに右慢性硬膜下血腫を有し, 慢性硬膜下血腫穿頭灌流除去術のみで症状の軽快をみ た。症例34江前額部陥没骨折直下に脑内小血腫をみたも ので, 骨片除去, 外減压術のみで好転した。

\section{外傷性脳内血腫に対する手術成精}

最後に手術成績についてまとめると, 脳内血腫除去術 を施行した12例では良好10例，死亡 2 例であり，硬膜下血 腫が主体であった 2 例妾除くと10例中良好 9 例, 死亡 1 例であった. Repcat CT にて血腫の增大ないし形成 の明らかであった 6 例の手術結果法, 良好 5 例, 死亡 1 例で西った。術後合倣症注 3 例にみられたが，DIC 2 例 (らち 1 例が死亡), 術後脑内血腫再貯溜 1 例で, いずれ も第 2,3 群の症例であった。
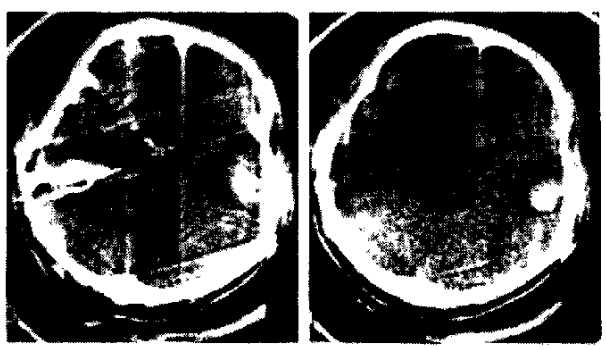

CT-1 (4 days)
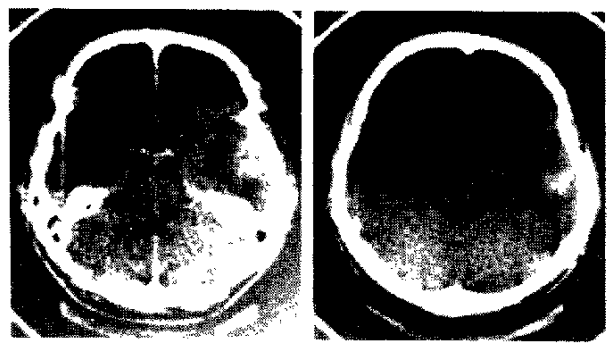

CT-2(11 days)

Fig. 7 Sequential CT's of Case 24. Note the decrease in size and density of the right temporal ICH.

$$
\mathrm{N} \text { 考察 }
$$

CT 導入後に我々が経験した外傷性脑内血腫34例を， 経時的な CT の観察結果を主体に上記のように4 群に 分類してみた．臨床症候の増㭧に関し2，3の例では硬 膜下血腫の増大なども関与している可能性はあるが，腦 


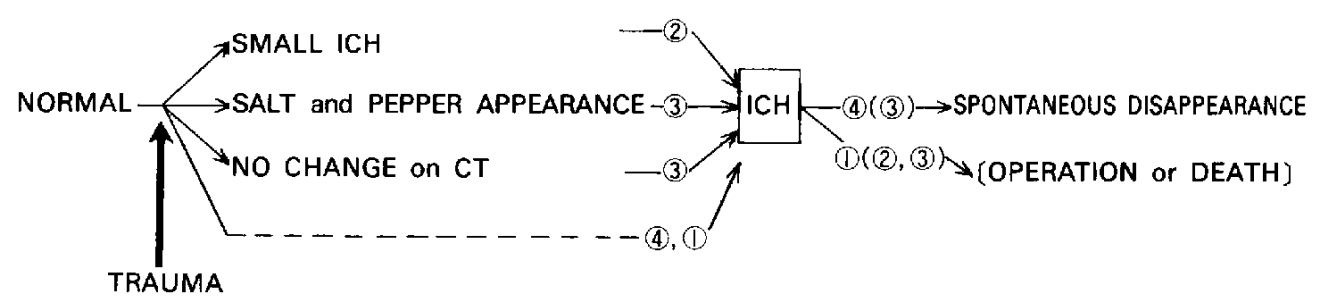

Fig. 8 Positioning of the classified groups into the sequential CT changes of traumatic intracerebral hematomas

(ICH). Number in circle denotes each group.

内血腫の消長が意識レベル，神経症状の推移とよく一致 することは結果の各項で記載したとおりである。これら 各群を CT 上の変化と対态させて図示したのが Fig. 8 であるが，第 2，3 群は主として脳内血瘇が完成するま での相を，第4群は完成した肶内血腫が消裉するまでの 相を見ていることになる。実際に診療に携わる者にとっ て脳内血腫例がどの程度の割合でどのような経過をとる ものかを知ることは重要なことと考えられるが，本分類 はその解明に役立つものと考えられる。

近年 CT が開発されてから Brown $ら^{5)}, \operatorname{Diaz} ら^{(3)} の$ ように経時的 CT で譄内血腫形成が明らかになった むののみをとりあげ “Delayed traumatic intracerebral hematomas"と称して討論しているが，そのよらな例が 嗵内血腫と診断されたもののうちどのような位直を占め ているかについては十分に考察していない，本論文では この点老中心に論じてみる.

まず比較を容易にする意味で，入院時 CT だ大血尰 と診断されたものについて診断生での経緯を検討してみ る. 第 1 群 5 例, 第 3 群 1 例, 第 4 群 4 例の合計 10 例が これに相当するが，受傷より入院までの時間が 6 時間以 内 1 例， $6 \sim 12$ 時閒 1 例，12 24時間 5 例， $2 \sim 7$ 日 3 例と，12時間孛経渦してからの例が $80 \%$ 占め，(半)清 明期を乐たものが 8 例，80\%であった，受傷直後より高 度の意識障書を呈し (半) 清明期がなくかつ6時間以内 に大血腫形成が見られていたのは1例にすぎなかった. すなわち脳内大血腫例の大半は少なくとも6 時間以上を かけて発達してきたのではないかと考えられる。またこ れらは，宮崎のが26例の，外傷性脳内血腫と診断される までの意譏レベルの推移の険討から，広義に間歇期を有 したものが84.6\%に達するとしたことに一致する。

次に第 2，3群に代表される repeat CT（1例は剖 検）で脳内血腫の形成ないし増大が明らかにされた10例 を検討してみると，受賃より入院なでの時間は全例が 6.5時閒以内と非常に早いものであった，その時点でCT 上脳内血腫と診断しえたのは第 2 群の 3 例であるが，い ずれも小血踵であった，症例14，15を除く8例は，最短
3.5時間，最長55時間の経過で CT 上明らかな脳内血腫 の形成ないし增大を認めた，症例14，15は硬膜外あるい は硬膜下血腫術後 7〜10日後に見い出したもので，特に この 2 例は璃内血腫形成時期に関しては不明である，症 例13は比較的急速に意識障害の発現を子たが，他の9例 は時間の長短㤌あるが徐々に悪化した。このうち最終的 に大血腫之診断された 6 例の受賃から診断までの時間を みると, $6 \sim 12$ 時間 2 例, $12 \sim 24$ 時間 1 例, $2 \sim 7$ 日 3 例であった。これらのことは上記の入院時大血腫と診断 された例の診断前䅅過とよく類似していることがわか る.才なわち，第 2,3 群で代表される症例の大半は，以 わば通常の外稘性媨内血腫の急性期での変化を単に CT で把握することができた症例と考えられるのである。

従来 “Delayed traumatic intracerebral hematomas" と いわれているものは，次の 2 つが代表的なるのと考えら れる. すなわち, Bollinger"1 $の$ traumatische Spät-Apoplexieの 概念索継承した Austerheim ${ }^{2}$ ) の criteria（突然に strokeとして発症すること，受傷より weeks or months 経過 してから発症すること等の6項目)を满足しなければな らないむのと, Baratham らうがまとめた内容のむの(受 傷後簡単な質問に合理的な返事ができるまでの意識しへ ルが得られたことのある症例群)である。しかし，CT 出 現後注Frenchら》が repeat CTで鼡内血腫形成をみた 1 例に traumatische Spät-Apoplexie しいら形容安つ村て以

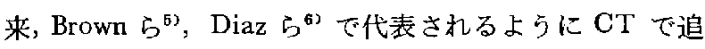
跡し脳内血腫形成妾確認しえた例に“Delayed traumatic intraccrebral hematomas" と呼称するよらになってしま った. Diazら $ら^{6)}$ は一応その criteria として Austerheim², Baratham ら゙のそれと類似したるのとしているが，受賃 から 2 週以内に発生したものといら点で Austerheim ${ }^{22}$ は意見を異にするものであり， permanent loss of consciousness 例を含めた点から Baratham ら なり異なったものにしている. Brown ら $ら^{52}$, Diaz ら 症例をみると我々の第 $2 ， 3$ 群のそれとほぼ一致してお り，CTで血腫の形成〜増大を証明した例にすきないよ らに思われる。文献上 “Delayed traumatic intracerebral 
hematomas"の定義, criteria kついて意見が一致して

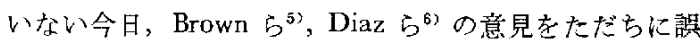
りであるとすることはできないが，我々はこのような症 例飞 "Delayed traumatic intracerebral hematomas" $と い$ う名称を与えることに㱡成できない，また Brown ら はこのような例はかなり稀であるとしているが，我各の 症例では34例中10例もありかなり多いものであることが わかる。

有賀ら" は外傷性腷内血腫生成に関し，手術時の血腫 の性状と時間的な推移から，数時間以内に形成される massive hamatoma $の$ carly type $と 12$ 時間以上の経過で 形成される contusional hematoma $の$ delayed type に分 類しているが，我々の症例でみる限りこの上らに一概に は言い切れず，な扮检討を要するるのと考えている。

Repeat CT にて血腫の増大 形成が証明された 10 例 の初问 CT での血腫部位の所見を検討すると,大きく3 つに分けられた（Fig．8).すな⿰力口，1)小血腫のもの (第 2 群の 3 例)，2) salt and pepper appearance 示寸 むの(第 3 群の 4 例)挍上び 3) CT 上変化のないもの(第 3 群の 3 例) であった。、いが考えうるすべての所見か ら䐉内血腫形成があったことになる。この初回 CT T゙の 所見については Diaz ら ${ }^{6)}$ は脳外血腫との組み合わせに より 4 型に分類しているが，脳内血腫部位での所見沙我 々のものとほぼ一致している。なお，CT 上変化のない ものを脳挫稘由来として第 3 群に入れたのは，最終的に 確認しえた血腫の所見が一部集簇性であったり，周囲低 吸収域が著明であったことによる。

Diaz $ら^{6)}$ は repeat CT で脳内血腫形成者みた症例の 治療成績が不良であることを報告したが，我んの症例の 結果では10例中良好 7 例, 死亡 3 例（手術症例 6 例では 良好 5 例, 死亡 1 例) とまず主の成績を得た。 Diaz ら ${ }^{6>}$ の症例に比べ入院時の意識障害方軽度の症例が多か ったことにもよると考えられる。しかし手術例 6 例のう ち2例に DIC 合併し，5ち1例走失っている，2例 ともに頭部以外に出血索生じた外傷があったことに起因 するとも思われ，管理上注意す心゙きものと思われた。

最後に外傷性脳内血腫の手術適応について簡単に子れ たい.Weigcl ら ${ }^{10} は \mathrm{CT}$ 導入後の31例の経験から，60 分以上の脳幹症候を呈したもの，脳内血腫が小さいも の，臨床状態が自然に好転するものは手術適応外とし， 臨床上増悪する例にのみ適応があるとしているが，我タ の34例の経験加もまったく同感である。第 4 群の大血 腫 4 例でもわかるように，大血腫といえども保存的治潦 で軽快することがあるため，各症例において手術適応汕 慎重に決定すべきであうう，その際に臨床経過の笽重な
観察と repeat CT が重要であることは言うまでもない こ上と思わ机る8.

\section{Vおわりに}

CT 導入後に経験した34例の外稘性脳内血腫を, 主と して CTの経時的観察結果をもとに4 群に分類した. こ れら各群を検討した結果，CT 上の腷内血腫の増大（形 成）ないし縮小の所見と意識レベル，神経症侯の推移が よく一致していることが判明した。

近年 Brown ら ${ }^{52}$ ，Diaz ら ${ }^{(3)}$ はCT で脳内血腫の形 成～増大を追䟢しえた症例に対し “Delayed traumatic intracerebral hematomas”と称し報告しているが，我ヶ の症例抽よび文献上の考察から，これらは通常の外傷性 檤内血腫急性期例の CT で血腫形成を確認しえた 症例 にすぎないであるらことを述べた。

本論文の要旨は第37回日本胘神経外科学会（熊本）に て登表した，稿を終るにあたり，御校閲いただいた群馬

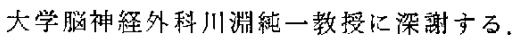

\section{文献}

1) 有賀 徹, 益澤秀明, 水谷 弘, 三井香児, 江口恒良, 佐野圭司: 外傷性䋞内血腫の生成, CT 上遷延型発生寺した症例から。 Neurol Med Chir (Tokyo) 19: 459-466, 1979

2) Austerherm, K.: Delayed traumatic intracerebral hemorrhage (Bollingcr's SpätApoplexie), Report of one case with necropsy. Acta Pathol Microbiol Scand 38: 177-185, 1956

3) Barntham, G. \& Dennyson, W. G.: Delayed traumatic intracerebral haemorrhage. $J$ Neurol Neurosurg Psychiatry 35: 698-706, 1972

4) Boltrivger, O.: Ueber traumatische SpätApoplexie, Ein Beitrag zur Lehre von der Hirnerschütterung. Internationale Beitrage zur Wissenschaftlichen Medizin. Festschrift, Virchow, R. Berlin: A. Hirschwald, Vol. 2, 1891, pp 457-470

5) Brown, F. D., Mullan, S. \& Duda, E. E.: Delayed traumatic intracerebral hematomas. Report of three cases. $J$ Neurosurg 48: 1019 1022,1978

6) Diaz, F. G., Yock, D. H., JR., Larson, D. \& Rockswold, G. L.: Early diagnosis of delayed posttraumatic intracerebral hematomas. $J$ Neurosurg 50: 217-223, 1979

7) French, B, N. \& Dublin, A. B.: The value of computerized tomography in the management of 1000 consecutive head injuries. Surg Neurol 7: 171-183, 1977 
8）河野和幸, 深町 彰, 田崎 健, 小泉英仁, 若尾哲夫：外傷性脳内血腫のC T 所見,特にC T の経時的観察の重要性について. C T 研究 1 : 345-354, 1979

9）宮崎雄二：外傷性脳内血腫について，朕神経 $20: 1101-1112,1968$

10) Weigel, K., Ostertag, C. B. \& Mundinger,
F.: CT follow-up control of traumatic intracerebral hemorrhage. pp 62-67, In Frowein, R. A., Wilcke, O., Karimi-Nejad, A., Brock, M. \& Klinger, M. (eds): Advances in Neurosurgery, Volume 5, "Head Injuries, Tumors of the Ccrebellar Region", Springer Verlag, Berlin Heidelberg, New York, 1978 